\title{
URGENSI DAN EKSISTENSI UNDANG-UNDANG PERLINDUNGAN KONSUMEN TERHADAP PRAKTIK BISNIS
}

\author{
Moh Abdul Latif \\ Institut Agama Islam Negeri Kudus \\ Email: lathifabd666@gmail.com
}

\begin{abstract}
Business practices in the era of disruption were apparently very much unethical or even totally unethical so naturally in practice they led to criminal acts of fraud and crime especially seminar business practices which promised great benefits for consumers, but in fact caused unrest among the people of Indonesia. The purpose of this paper is to analyze the forms of consumer protection for victims of business practices that contain elements of criminal acts based on the Law of Number 8 of 1999 concerning Consumer Protection. This type of research that will be used is in the form of juridical-normative research which covers the systematic of a law. From this research it can be concluded that consumer protection of business practices is very important to be implemented against cases of fraudulent business practices under the guise of seeking profit.
\end{abstract}

Keywords: Consumer Protection, Business Practices, Legislation

\begin{abstract}
Abstrak
Praktik bisnis di era disrupsi ternyata banyak sekali yang kurang beretika atau bahkan sama sekali tidak beretika sehingga tentunya dalam praktik tersebut mengarah kepada tindak pidana penipuan dan kejahatan khususnya praktik bisnis seminar yang menjanjkan keuntungan yang besar bagi konsumen, namun faktanya menimbulkan keresahan di kalangan masyarakat Indonesia. Tujuan dalam penulisan ini untuk menganalisis bentuk perlindungan konsumen terhadap korban praktik bisnis yang mengandung Unsur Tindak Pidana Berdasarkan Undang-Undang Nomor 8 Tahun 1999 tentang Perlindungan Konsumen. Jenis penelitian yang akan digunakan adalah berupa penelitian yuridis-normatif yang mencakup tentang sistematika suatu hukum. Dari penelitian ini dapat disimpulkan bahwa perlindungan konsumen terhadap praktik bisnis sangat penting di implementasikan terhadap kasus-kasus penipuan praktik bisnis yang berkedok untuk mencari keuntungan.
\end{abstract}

Kata Kunci: Perlindungan Konsumen, Praktik Bisnis, Perundang-Undangan 


\section{PENDAHULUAN}

Pendidikan di Indonesia tentunya semakin hari juga semakin baik, terbukti dengan semakin banyaknya masyarakat yang telah menempuh pendidikan yang lebih tinggi semakin meningkat dan banyak. Akan tetapi, akibat dari hal tersebut tentunya memberikan konsekuensi yang sangat besar, terutama meningkatnya angka pengangguran akibat banyaknya lulusan-lulusan yang telah dikeluarkan dari institusi pendidikan. Jumlah angkatan kerja pada Februari 2019 sebanyak 136,18 juta orang, naik 2,24 juta orang dibanding Februari 2018. Sejalan dengan naiknya jumlah angkatan kerja, Tingkat Partisipasi Angkatan Kerja (TPAK) juga meningkat sebesar 0,12 persen poin.Dalam setahun terakhir, pengangguran berkurang 50 ribu orang, sejalan dengan TPT yang turun menjadi 5,01 persen pada Februari 2019. Dilihat dari tingkat pendidikan, TPT untuk Sekolah Menengah Kejuruan (SMK) masih tertinggi diantara tingkat pendidikan lain, yaitu sebesar 8,63 persen.

Penduduk yang bekerja sebanyak 129,36 juta orang, bertambah 2,29 juta orang dari Februari 2018. Lapangan pekerjaan yang mengalami peningkatan persentase penduduk yang bekerja terutama pada Penyediaan Akomodasi dan Makan Minum (0,43 persen poin), Perdagangan (0,39 persen poin), dan Konstruksi (0,34 persen poin). Sementara lapangan pekerjaan yang mengalami penurunan utamanya pada Pertanian (1,00 persen poin); Administrasi Pemerintahan (0,23 persen poin); serta Informasi dan Komunikasi (0,06 persen poin). Sebanyak 74,08 juta orang $(57,27$ persen) bekerja pada kegiatan informal.

Selama setahun terakhir (Februari 2018-Februari 2019), pekerja informal turun sebesar 0,95 persen poin.Persentase tertinggi pada Februari 2019 adalah pekerja penuh (jam kerja minimal 35 jam per minggu) sebesar 69,96 persen. Sedangkan penduduk yang bekerja dengan jam kerja 1-7 jam memiliki persentase yang paling kecil, yaitu sebesar 2,69 persen. Sementara itu, pekerja tidak penuh terbagi menjadi dua, yaitu pekerja paruh waktu (22,67 persen) dan pekerja setengah penganggur $(7,37$ persen). Rata-rata upah buruh berdasarkan hasil Sakernas Februari 2019 sebesar 2,79 juta rupiah.Rata-rata upah buruh laki-laki sebesar 3,05 juta rupiah dan rata-rata upah buruh perempuan sebesar 2,33 juta rupiah.Terdapat 7 dari 17 kategori lapangan pekerjaan dengan rata-rata upah buruh lebih rendah daripada rata-rata upah buruh nasional.Ratarata upah buruh berpendidikan universitas sebesar 4,34 juta rupiah, sedangkan buruh berpendidikan Sekolah Dasar ke bawah sebesar 1,73 juta rupiah (Badan Pusat Statistik, Statistik Angka Kemiskinan dan Pengangguran, 2019).

Tentu saja akibat fenomena tersebut diatas, banyak elemen masyarakat yang mencari akal ataupun cara lain demi mendapatkan pekerjaan ataupun mendapatkan penghasilan tambahan dengan 
mengikuti praktik bisnis berbasis ekonomi ataupun entrepreneurship, dan lain-lain. Tentunya dengan mengikuti praktik bisnis tersebut, diharapkan mereka mendapatkan ilmu, maupun kiat-kiat berbisnis sehingga mereka mendapatkan hak-hak mereka sebagai konsumen. sebagai kajian adalah praktik bisnis seminar, dalam praktiknya ternyata banyak sekali seminar yang berpraktik secara kurang beretika atau bahkan sama sekali tidak beretika sehingga tentunya mengarah kepada tindak pidana seperti penipuan. Sebagai contohnya adalah sebagai berikut : (Idris Rusadi Putra, hati-hati penipuan investasi berkedok seminar, begini modusnya)

"Badan Pengawas Perdagangan Berjangka Komoditi (Bappebti) Kementerian Perdagangan RI menghimbau kepada para khalayak masyarakat supaya berhati-hati terhadap penipuan investasi berkedok pelatihan atau seminar perdagangan ataupun seminar bisnis. Hal ini umumnya dilakukan oleh para pialang ilegal karena modus yang digunakan semakin maju dan canggih. Motif penipuan para pialang ilegal semakin maju sesuai denganpekembangan jaman dan selalu mencari celah baru, walaupun hingga aturan mengenai perdagangan ataupun bisnis berjangka komoditas di Indonesia telah mencapai 120 regulasi. Korbannya terdiri dari berbagai lapisan masyarakat dari anak sekolah seperti mahasiswa hingga pengusaha yang telah berkembang pesar pun tergiur dan tertarik dengan keuntungan yang sangat besar dengan syarat mudah yang ditawarkan oleh para pialang ilegal "

Pemerintah tentunya mempunyai instrumen ataupun tools untuk dapat menjamin suatu penyelenggaraan perlindungan konsumen, maka pemerintah menuangkan Perlindungan Konsumen dalam suatu Produk hukum. Hal ini penting karena hanya hukum yang memiliki kekuatan untuk memaksa pelaku usaha untuk menaatinya, dan juga hukum memiliki sanksi yang tegas. Mengingat dampak penting yang dapat ditimbulkan akibat tindakan pelaku usaha yang sewenang-wenang dan hanya mengutamakan keuntungan dari bisnisnya sendiri, maka pemerintah memiliki kewajiban untuk melindungi konsumen yang posisinya memang lemah, di samping ketentuan hukum yang melindungi kepentingan konsumen belum memadai (Undang-Undang Nomor 8 Tahun 1999, Tentang Perlindungan Konsumen).

Konsumen mempunyai hak untuk dilindungi dari praktik bisnis seminar yang tidak beretika. Tentunya akibat dari maraknya praktik bisnis seminar yang mengandung unsur sebagai contoh berita diataskonsumen dalam hal ini menjadi korban dan akibat lemahnya posisi dari konsumen tidak dapat berbuat apa-apa. Tentu saja, pemerintah dalam hal ini tidak tinggal diam terbukti dengan dibentuknya UndangUndang Nomor 8 Tahun 1999 tentang Perlindungan Konsumen. Akan tetapi, Undang-Undang tersebut hanya melindungi konsumen yang menjadi korban tanpa adanya upaya preventif/upaya pencegahan untuk 
melindungi konsumen dari korban tindak pidana. Pengawasan pemerintah dalam hal penyelenggaraan konsumen berdasarkan Peraturan Pemerintah Tahun 2001 Tentang Pembinaan dan Pengawasan Penyelenggaraan Konsumen, yang didalam Pasal 2 berbunyi bahwa dalam hal ini pemerintah bertanggung jawab terhadap pembinaan atas penyelenggaraan perlindungan konsumen yang memberikan jaminan akan diperolehnya Hak konsumen serta pelakuusaha. Pasal 7 sampai dengan Pasal 11 Undang-undang tersebut hanya menjelasakan terkait pengawasan dengan cara penelitian, pengujian, dan survey tanpa adanya penjelasan secara lebih lanjut terkait dengan pengawasan perlindungan konsumen yang mengandung kesesatan informasi sehingga dalam hal tersebut dapat mengandung unsur tindak pidana. Dalam hal ini, seminar juga merupakan sebagai suatu contoh bentuk jasa.

Sebagai contoh analogi "A sebagai pelaku usaha, dia menyelenggarakan seminar dengan baliho besar dengan judul Headlne "Ikutilah seminar bisnis membeli properti tanpa rumah tanpa hutang dengan A yaitu saya sendiri sebagai Mentor bisnis, gratis!". Dalam hal itu, B sebagai konsumen tertarik sehingga mengikuti seminar bisnis tersebut. Akan tetapi, pada saat B mengikuti seminar tersebut, untuk mengikuti bisnis lanjutan dia harus membayar sejumlah uang. Demi tercapainya hal tersebut, B membayarkan sejumlah uang. Akan tetapi alangkah terkejutnya B pada saat telah membayar biaya lanjutan tersebut, ternyata cara ataupun ilmu yang diberikan A sebagai mentor tidak masuk akal atau sebenarnya bahkan tidak dapat dilakukan (Himam Miladi, Membongkar Pembodohan “Beli Property Tanpa Modal Tanpa Utang). Tentunya dalam hal ini, B sebagai konsumen yang mendapatkan suatu kesesatan informasi tersebut hanya dapat pasrah, padahal sebenarnya haknya sebagai konsumen telah dilanggar, hanya saja tidak ada tindakan atau upaya preventif dari pemerintah sebagai entitas dari perlindungan konsumen tersebut. Entitas perlindungan konsumen tersebut tentunya kedepannya dibutuhkan suatu konsep semacam perizinan penyelenggaraan seminar, dalam hal ini Lembaga Perlindungan terkait dengan Konsumen Swadaya Masyarakat atau yang lebih dikenal dengan LPKSM harus menguji kelayakan suatu seminar, dan pemberian izin dapat atau tidaknya dilakukan seminar tersebut".

\section{METODE PENELITIAN}

Jenis penelitian yang digunakan adalah penelitian yuridis-normatif yang mencakup tentang sistematika suatu hukum. Penelitian yuridisnormatif adalah suatu prosedur ilmiah untuk menemukan kebenaran berdasarkan logika keilmuan dari sisi normatifnya yang obyeknya hukum itu sendiri (Ibrahim, 2011: 57). Penelitian yuridis normatif membahas doktrin-doktrin atau asas-asas dalam ilmu hukum (Ali, 2011 : 24). Selain 
asas-asas, ketentuan perundang-undangan tertentu dapat pula berisi asasasal lain tentunya sesuai dengan bidang hukum ketentuan perundangundangan yang bersangkutan. Sebagai contoh doktrin iktikad baik, doktrin fakta hukum dan sebagainya (Ali, 2011 : 24).

Penelitian ini merupakan penelitian hukum yang dilakukan dengan meneliti bahan pustaka atau data sekunder. Metode penelitian hukum merupakan cara penguraian pelaksanaan penelitian yakni pendekatan penelitian yang digunakan hingga menganalisis hasil penelitian. penilitian hukum normatif ini adalah suatu penelitian hukum doktriner, dan juga disebut pula sebagai suatu penelitian hukum pustaka atau studi dokumen. Disebut penelitian hukum doktriner sebab penelitian ini dilakukan ataupun ditujukan hanya terkait denganperaturan-peraturan yang tertulis atau bahan-bahan hukum yang lain. Sedangkan disebut dengan penelitian pustakaataupun studi dokumen disebabkan karena penelitian ini lebih banyak dilakukan terhadap data yang bersifat sekunder yang hanya ada di perpustakaan.

\section{PEMBAHASAN}

Bentuk perlindungan terhadap masyarakat tentunya bermacammacam salah satu bentuknya yaitu dengan cara memberikan perlindungan hukum. Adanya kontra kepentingan didalam kehidupan masyarakat harus dapat diminimalisir dengan hadiranya hukum didalam masyarakat. Keharusan memberikan perlindungan hukum bagi seluruh bangsa Indonesia dapat ditemukan dalam Undang-Undang Dasar Negara Republik Indonesia Tahun 1945. Oleh karena itu, setiap produk yang dihasilkan oleh legislatif harus mampu memberikan perlindungan hukum bagi seluruh masyarakat. Terdapat beberapa pendapat para sarjana mengenai perlindungan hukum, antara lain : (Rahardjo, 2003 : 121).

1) Menurut Satjipto Rahardjo, perlindungan hukum adalah suatu upaya untuk melindungi hak-hak seseorang dengan cara menentukan banyaknya suatu kekuasaan terhadapnya untuk berlaku maupun bertindak dalam rangka suatu kepentingannya tersebut.

2) Menurut Philipus M. Hadjon, perlindungan hukum diartikan sebagai tindakan melindungi atau memberikan suatu pertolongan terhadap subjek hukum dengan perangkat-perangkat hukum. Bila melihat pengertian perlindungan hukum di atas, maka dapat diketahui unsurunsur dari perlindungan hukum, yaitu: (Saliman, 2008 : 23) subyek yang melindungi, obyek yang akan dilindungi alat, instrumen, maupun upaya yang digunakan untuk tercapainya perlindungan tersebut.

Dari beberapa pengertian mengenai perlindungan hukum di atas, dapat disimpulkan bahwa perlindungan hukum sebagai suatu upaya 
untuk melindungi kepentingan individu atas kedudukannya sebagai manusia yang mempunyai hak untuk menikmati martabatnya, dengan memberikan kewenangan padanya untuk bertindak dalam rangka kepentingannya tersebut.

Konsumen merupakan pengguna akhir (end user), dari suatu produk yaitu setiap dari perilaku konsumerisme barang dan/atau jasa yang ada atau tersedia didalam masyarakat entah itu bagi kepentingannya sendiri, keluarga, orang lain, ataupun makhluk hidup yang lain dan hal ini tentunya tidak untuk dijadikan barang perdagangan (Saliman, 2008 : 23)

Pengertian konsumen dapat terdiri dari tiga pengertian, yaitu (Nugroho, 2008 : 61):

1) Konsumen adalah individu-individu yang memperoleh barang danatau jasa yang dipergunakan dalam hal tertentu.

2) Konsumen adalah setiap individu-individu yang mendapatkan suatu barang atau jasa dipergunakan untuk diperdagangkan/komersial. Melihat pada sifat penggunaan barang dan/atau jasa, konsumen antara ini sesungguhnya adalah pengusaha, baik pengusaha perorangan maupun pengusaha yang berbentuk badan hukum atau tidak, baik pengusaha swasta maupun pengusaha publik (perusahaan milik negara) dan dapat terdiri dari penyedia dana (investor), pembuat produk akhir yang digunakan oleh konsumen akhir atau produsen, atau penyedia atau penjual produk akhir seperti supplier, distributor atau pedagang.

3) Konsumen akhir adalah setiap orang alami yang mendapatkan barang dan/atau jasa, yang digunakan untuk tujuan memenuhi kebutuhan hidup pribadinya, keluarga dan rumah tangganya dan tentunya hal ini tidak untuk diperdagangkan kembali.

\section{Hak-Hak Konsumen}

Peraturan terkait perlindungan konsumen telah diatur didalam Undang-Undang Nomor 8 Tahun 1999 tentang Perlindungan Konsumen. Pada tanggal 30 Maret 1999, Dewan Perwakilan Rakyat atau DPR ternyata telah menyepakati suatu rancangan undang-undang atau RUU yang terkait dalam hal perlindungan konsumen yang disahkan oleh pemerintah yang ternyata selama 20 tahun selalu diperjuangkan. RUU ini ternyata baru disahkan oleh pemerintah-pemerintah terkait pada tanggal 20 bulan April tahun 1999. Tentunya dengan diundangkannya hal tersebut masalah yang terkait dengan perlindungan konsumen dapat dimungkinkan untuk melakukan pembuktian terbalik jika ternyata nantinya terjadi suatu sengketa yakni antara konsumen dengan pelaku usaha. Konsumen yang dalam hal ini merasa bahwa kepentingannya dilanggar dapat mengadukan ataupun memproses perkaranya melalui jalur hukum di 
Badan Penyelesaian Sengketa Konsumen atau yang dikenal dengan nama BPSK yang telah tersedia di Indonesia (Susanto, 2008 :20).

Menurut ketentuan dari Pasal 4 Undang-undang terkait dalam hal Perlindungan Konsumen, Hak-hak Konsumen disebutkan disusun secara sistematis (mulai dari yang diasumsikan paling dasar), akan diperoleh urutan sebagai berikut (Kristiyanti, 2008 : 32):

a. Hak ataupun kepentinganagar mendapatkan suatu informasi yang benar dan jelas: Setiap produk yang ditawarkan terhadap konsumen haruslah disertakan informasi yang jelas, benar, dan jujur. Informasi ataupun petunjuk ini diperlukan oleh konsumen agar tidak sampai mendeskripsikan suatu hal yang salah ataupun keliru terkait dengan produk yang dalam hal ini berbentuk barang ataupun jasa. Informasi petunjuk ini tentunya dapat disampaikan dengan dengan berbagai cara, seperti lisan kepada konsumen, melalui iklan di berbagai media atau mencantumkan dalam kemasan produk (Kristiyanti, 2008 : 32). Jika dikaitkan dengan hak konsumen atas keamanan, maka setiap produk yang mengandung resiko terhadap keamanan konsumen wajib disertai informasi berupa petunjuk pemakaian yang jelas. Sebagai contoh, iklan yang secara ideal diartikan sebagai sarana pemberi informasi kepada konsumen, seharusnya terbebas dari manipulasi data. Jika iklan memuat informasi yang tidak benar, maka perbuatan itu memenuhi kriteria kejahatan. kejahatan ini mempunyai ciri-ciri diantaranya adalah sebagai berikut (Kristiyanti, 2008 : 32):

1) Mempergunakan pernyataan yang secara terang-terangan keliru atau salah (false statement).

2) Pernyataan yang menyesatkan (mislead), misalnya menyebutkan adanya khasiat tertentu padahal tidak.

b. Hak ataupun kepentingan untuk mendapatkan suatu produk yakni barang ataupun jasa yang sesuai dengan jumlah atau nilai tukar yang diberikan terhadapnya, ini berarti konsumen wajib dilindungi dalam hal terkait dengan monopoli harga yang sangat tidak masuk akal. Kuantitas dan kualitas barang dan/atau jasa yang dikonsumsi oleh konsumen haruslah tepat dan sesuai dengan nilai tukar dari uang yang dibayarkan sebagai pengganti dari jumlah yang dibayarkan tersebut. tetapi, pelaku usaha bisa saja mendikte atau menyuruh pasar dengan cara menaikkan harga yang tidak wajar dan tentunya dalam hal ini konsumen lagi-lagi menjadi korban dari tidak adanya pilihan lain. Dalam situasi ataupun hal yang demikian ini, konsumen akhirnya terpaksa mencari produk-produk alternatif lainnya apabila masih ada, yang tentunya kualitasnya ternyata lebih buruk. Dampak dari tidak imbangnya posisi tawar-menawar diantara pelaku usaha dengan konsumen, tentunya pihak pertama dalam halbisa saja membebankan 
biaya-biaya yang tentunya dalam hal ini biaya tersebutbukan merupakan tanggung konsumen.

c. Hak atau kepentingan untuk mendapatkan suatu ganti rugi : apabila konsumen merasa kuantitas dan kualitas barang ataupun jasa yang dikonsumsinya tidak tepat ataupun tidak sesuai dengan jumlah ataupun nilai tukar yang diberikan terhadapnya, maka konsumen berhak untuk mendapatkan suatu ganti rugi yang sesuai dengan tingkat kerugiannya. Untuk menghindari kewajiban untuk memberikan ganti rugi, biasanya pelaku usaha mencantumkan klausula-klausula eksonerasi yang di dalamnya terdapat suatu hubungan hukum antara produsen ataupun penyalur produk dan juga terhadap konsumennya. Pencantuman secara sepihak ini tentunya tidak dapat menghilangkan hak-hak konsumen yang ada dan konsumen tetap dapat mendapatkan ganti rugi atas kerugian yang dideritanya.

d. Hak untuk mendapat penyelesaian hukum : Hak untuk mendapatkan ganti kerugian harus ditempatkan lebih tinggi daripada hak pelaku usaha (produsen/penyalur produk) untuk membuat klausula eksonerasi secara sepihak. Jika permintaan yang diajukan konsumen dirasakan tidak mendapat tanggapan yang layak dari pihak-pihak terkait dalam hubungan hukum dengannya, maka konsumen berhak mendapatkan penyelesaian hukum, termasuk advokasi. Dengan kata lain, konsumen berhak menuntut pertanggungjawaban hukum dari pihak-pihak yang dipandang merugikan karena mengonsumsi produk itu.

e. Hak atapun kepentingan untuk dilindungi dari dampak yang terkait dalam hal persaingan curang: Persaingan curang dapat terjadi jika seorang pengusaha berusaha menarik langganan atau klien pengusaha lain untuk memajukan usahanya atau memperluas penjualan atau pemasarannya dengan menggunakan alat atau sarana yang bertentangan dengan itikad baik dan kejujuran dalam pergaulan perekonomian.Walaupun persaingan terjadi antara pelaku usaha, namun dampak dari persaingan itu selalu dirasakan oleh konsumen. Jika persaingan sehat, konsumen memperoleh keuntungan. Sebaliknya jika persaingan curang konsumen pula yang dirugikan. Kerugian itu boleh jadi tidak dirasakan dalam jangka pendek tetapi cepat atau lambat pasti terjadi.

Mengenai kewajiban-kewjiban konsumen yang tercantum didalam

Pasal 5 Undang-Undang Nomor 8 Tahun 1999 meliputi hal-hal sebagai berikut :

1) Kewajiban konsumen untuk membaca ataupun mengikuti informasi atau petunjuk dan proseduraturan pakai atau pemanfaatan dari suatu 
barang dan/atau jasa, demi keamanan dan juga keselamatan konsumen tersebut;

2) beritikad yang baik dalam hal melakukan suatu transaksi pembelian dari suatu barang dan/atau jasa tersebut;

3) membayar biaya yang tentunya harus sesuai dengan nilai tukar yang telah disepakati;

4) mengikuti upaya-upaya penyelesaikan sengketa-sengketa hukum yang terkait perlindungan konsumen yang terjadi terhadapnya dengan patut.

\section{Informasi Menyesatkan Sebagai Bentuk Tindak Pidana}

Berdasarkan Kamus Besar Bahasa Indonesia, 'Informasi' berarti : penerangan, pemberitahuan, kabar, atau berita tentang sesuatu, keseluruhan makna yang menunjang amanat yang terlihat dalam bagianbagian amanat itu. Sedangkan 'Menyesatkan' berasal dari kata 'Sesat' yang berarti : tidak melalui jalan yang benar, salah jalan, menyesatkan sendiri berarti membawa ke jalan yang salah, menyebabkan sesat. Apabila digabungkan kata perkata tersebut diatas, informasi yang menyesatkan berarti Suatu pemberitahuan ataupun kabar yang memuat tentang hal yang salah, keliru kearah yang sesat.

Didalam Undang-Undang Nomor 8 Tahun 1999 tentang Perlindungan Konsumen sesungguhnya tidak terdapat pengertian ataupun maksud mengenai Informasi yang menyesatkan, hanya ada dalil dalam Pasal 17 poin c dengan frasa "Memuat suatu petunjuk informasi yang berseberangan. keliru, salah, ataupun tidak tepat terkait dengan barang dan/atau jasa". Akan tetapi dalam Undang-Undang lain yakni Kitab Undang-Undang Hukum Pidana atau yang lebih dikenal dengan KUHP Pasal 390 terdapat ketentuan yang serupa walaupun sedikit berbeda yaitu digunakannya yakni dengan frasa Menyiarkan suatu kabar bohong.

Terdakwa hanya dapat dihukum dengan Pasal 390 KUHP, apabila ternyata bahwa kabar yang disiarkan itu adalah kabar bohong. Yang dipandang sebagai kabar bohong, tidak saja memberitahukan suatu kabar yang kosong, akan tetapi juga menceritakan secara tidak betul tentang suatu kejadian (Soesilo, 2008: 269). Dari pengetian tersebut, maka simpulan yang dapat diambil, pengertian tentang informasi yang menyesatkan, yaitu suatu Pemberitahuan yang terdapat suatu unsur yakni suatu kebohongan atau keliru yang mana dalam hal tentang perlindungan konsumen ini, mengakibatkan suatu kerugian oleh konsumen". 


\section{Bisnis seminar sebagai bentuk kegiatan corporasi}

Kata seminar beraawal dari suatu kata yakni Latin semin yang berarti "benih". Jadi, arti kata seminar yakni "suatu tempat terciptanya benih-benih kebijaksanaan". Seminar merupakan suatu pertemuan yang ilmiah yang secara sistematis mempelajari suatu hal ataupun topik yang khusus dibawah komando ataupun pimpinan seseorang yang ahli dan berkecimpung didalam bidang tersebut. Seminar merupakan suatu pertemuan ataupun persidangan yang didalamnya membahas suatu permasalahan di bawah pimpinan ketua sidang baik dalam hal ini orang tersebut adalah guru besar ataupun seseorang ahli. Pertemuan ataupun persidangan didalam seminar dalam hal ini biasanya menampilkan suatu ataupun beberapa topik pembicaraan dengan makalah ataupun suatu kertas kerja dari masing-masing bidang.

Seminar biasanya dilaksanakan untuk membahas suatu permasalahan ataupun suatu problematika apapun secara ilmiah. Adapun yang berpartisipasi ataupun orang yang mengikuti seminar tersebut tentunya adalah orang yang ahli dalam bidangnya. Begitu juga terkait denganseminar yang dimana dalam hal ini memasarkan suatu produk, seminar tersebut tentunya dihadiri oleh para orang-orang ataupun pakar yang ahli dibidang pemasaran, terkadang orang umum yang hendak mengikuti seminar terkait dengan bisnis untuk memajukan kehidupannya secara financial terkadang juga ikut menghadiri acara seminar tersebut. Seminar pendidikan tentunya juga dihadiri oleh orang-orang yang ahli pendidikan pesertanya pun dapat berupa masyarakat umum, pendidik, mahasiswa, mauapun siswa-siswa terpelajar yang lain. Sementara itu, para peserta dalam hal ini juga terkadang berperan untuk memberikan suatu pertanyaan, ulasan, ataupun pembahasan yang terkait dengan permasalahan yang menjadi topic seminar tersebut sehingga diharapkan dalam hal ini dapat menghasilkan suatu pemahaman yang dapat menyelesaikan suatupermasalahan tersebut (Lim Kristanto Sitompul, Pengertian Seminar, Diskusi, Simposium, dan Kolukium).

Bisnis dalam arti luas adalah suatu istilah umum yang menggambarkan suatu aktivitas dan institusi yang memproduksi barang dan jasa dalam kehidupan sehari-hari (Amirullah dan Hardjanto, 2005: 27). Menurut Indriyo Gito Sudarmo, ada beberapa macam jenis bisnis, untuk memudahkan mengetahui pengelompokannya maka dapat dikelompokkan sebagai berikut (Gitosudarmo, 2000: 3):

a. Ekstraktif, yaitu bisnis yang melakukan kegiatan dalam bidang pertambangan atau menggali bahan-bahan tambang yang terkandung di dalam perut bumi.

b. Agraria, yaitu bisnis yang menjalankan bisnisnya dalam bidang pertanian.

c. Industri, yaitu bisnis yang bergerak dalam bidang industri. 
d. Jasa, yaitu bisnis yang bergerak dalam bidang jasa yang menghasilkan produk-produk yang tidak berwujud.

Sedangkan pada Penelitian ini yang menjadi fokus peneliti adalah seminar yang dijadikan bisnis oleh para pelaku usaha. Dengan kata lain para pelaku usaha menjadikan suatu seminar sebagai kegiatan memproduksi jasa.

\section{Seminar Menyesatkan Sebagai Bentuk Kejahatan Corporasi}

Istilah tindak pidana berasal dari istilah yang dikenal dalam hukum pidana Belanda yaitu strafbaar feit, akan tetapi tidak ada penjelasan lebih lanjut tentang apa yang dimaksud dengan strafbaar feit itu (Chazawi, $2010: 67$ ).

Mezger memberikan definisi hukum pidana sebagai suatu tatanan atau aturan hukum/norma yang mengikat pada suatu perbuatan yang syarat-syarat tertentunya terpenuhi sebagai suatu akibat yang berbentuk pidana. Jadi pada dasarnya hukum pidana yang berpokok kepada 2 hal, yakni perbuatan yang memenuhi syarat-syarat tertentu, dan pidana.Yang dimaksud sebagai perbuatan yang syarat-syarat tertentunya terpenuhi adalah suatu perbuatan dimana perbuatan tersebut dilakukan oleh seseorang yang memungkinkan dijatuhi pidana akibat dari perbuatan yang dilakukannya. Perbuatan ini dengan singkat disebut perbuatan yang dapat dipidana. Untuk penjatuhan pidana diperlukan adanya perbuatan yang dilarang dan orang-orang yang melakukan larangan itu.Yang dimaksud dengan pidana adalah suatu penderitaan yang dengan sengaja diberikan atau dijatuhkan kepadanya oleh negara kepada tersangka ataupun orang yang melakukan suatu perbuatan yang dilarang atau bertentangan dengan aturan (tindak pidana) (Ruba'i, 1989: 7).

Dalam Kitab Undang-Undang Hukum Pidana atau yang lebih dikenal dengan KUHP, jenis-jenis pidana dirumuskan dalam pasal 10 yaitu terdiri atas Pidana Pokok, (Pidana mati,Pidana penjara,Pidana kurungan, Pidana denda) Pidana Tambahan (Pencabutan hak-hak tertentu, Perampasan Barang-barang tertentu, Pengumuman Putusan Hakim.) Dilihat dari garis besar, dan dengan berdasarkankepada kodifikasi sebagai suatu intisari ataupun suatu sumber pokok dari hukum pidana, hukum pidana adalah suatu bagian atas hukum publik yang didalamnya berisi beberapa ketentuan-ketentuan dalam hal (Chazawi, $2010: 2)$ :

a. Ketentuan umum terkait dengan hukum pidana dan hal-hal yang terkait ataupun berhubungan dengan beberapa larangan untuk melakukan suatu perbuatan-perbuatan (aktif ataupun positif maupun pasif ataupun negatif) tertentu yang dibarengi dengan ancaman terhadap sanksi yang berbentuk suatu hukuman (straf) terhadap individu-individu yang melanggar aturan tersebut. 
b. Prasyarat-prasyarat tertentu kapankah harus dipenuhi/ harus ada bagi pelanggar agar bisa dijatuhi suatu sanksi pidana yang diancam pada suatu larangan atas perbuatannya.

c. Perbuatan dan penanggulangan yang bisa atau wajib dilaksanakan oleh negara melalui alat-alat negara/tools of state (seperti jaksa, hakim, polisi) terhadap suatu yang disangkakam terhadap dirinya dan didakwakanakibat pelanggar hukum pidana dalam rangka upaya negara menentukan, menjatuhkan, dan melakukan sanksi pidana atas dirinya, jugadalam tindakan dan usaha-usaha yang dapat dan wajib untuk dilaksanakan oleh tersangka/terdakwa yang melakukan pelanggar hukum itu dalam upaya mempertahankan dan melindungi hak-hak tersangka/terdakwa tersebut atas tindakan dari negara sebagai usaha negara dalam pelaksanakan hukum pidana tersebut.

Berdasarkan hal di atas, tentunya kita dapat memahami bahwa konsumen ternyata adalah pihak yang lemah. Posisi konsumen sebagai pihak yang lemah juga diakui secara internasional sebagaimana tercermin dalam Resolusi Majelis Umum PBB, No.A/RES/39/248 Tahun 1985 tentang Guidelines for Consumer Protection, yang menyatakan bahwa :

"Taking into account the interests and needs of consumers in all countries, particularly those in developing countries, recognizing that consumers often face imbalances in economics terms, educational levels, and bargaining power, and bearing in mind that consumers should have the right of acces to non-hazardous products, as well as the right to promote just, equitable and sustainable econimic and social development.

Guidelines for Consumer Protection of 1985, yang menghendaki agar konsumen dimanapun mereka berada, dari segala bangsa, mempunyai hak-hak dasar tertentu, terlepas dari status sosialnya. Yang dimaksud dengan hak-hak dasar tersebut adalah hak untuk mendapatkan informasi yang jelas, benar, dan jujur, hak untuk mendapatkan keamanan dan keselamatan, hak untuk memilih, hak untuk didengar, hak untuk mendapatkan kebutuhan dasar manusia, hak untuk mendapatkan lingkungan yang baik, bersih, serta kewajiban untuk menjaga lingkungan itu, dan hak untuk mendapatkan pendidikan dasar. PBB mengimbau seluruh anggotanya untuk memberlakukan hak-hak konsumen tersebut di negaranya masing-masing. Guidelines for Consumer Protection ini berangsur-angsur mulai membuka mata pemerintah berbagai negata tentang praktik praktik ketidakadilan yang dialami konsumen sebagai salah satu pelaku ekonomi yang secara empiris keberadaannya diakui namun secara yuridis, dalam penyelesaian sengketa konsumen sulit dilaksanakan (Nugroho, 2011: 2-3). 


\section{Sanksi dalam Undang-Undang Perlindungan Konsumen}

Kebijakan kriminal atau politik kriminal secara singkat diartikan sebagai usaha yang rasional dan masyarakat untuk menanggulangi kejahatan. Untuk menyatakan sebuah perbuatan dapat dikatakan sebagai perbuatan pidana, sehingga mendapatkan sanksi pidana, Sudarto memberikan 4 kriteria yaitu (Sudarto, 1981: 73) :

1) Tujuan hukum pidana dikaitkan dengan tujuan nasional.

2) Penentuan perbuatan yang tidak dikehendaki.

3) Prinsip biaya dan hasil.

4) Kemampuan aparat penegak hukum.

Sedangkan dalam simposium Hukum Pidana pada 1980 di Semarang memberikan kriteria untuk mengadakan kriminalisasi dan diskriminalisasi sebagai berikut (Sudarto, 1981: 74):

1) Apakah perbuatan itu tidak disukai atau dibenci oleh masyarakat karena merugikan, atau dapat merugikan, aparat eksekusi,disamping usaha-usaha yang tidak menggunakan (hukum) mendatangkan korban atau dapat mendatangkan korban.

2) Apakah biaya mengkriminalisasi seimbang dengan hasilnya yang akan di capai, artinya cost pembuatan undang-undang, pengawasan dan penegakkan hukum serta beban yang dipikul oleh korban, pelaku kejahatan itu sendiri harus seimbang dengan situasi tertib hukum yang akan dicapai.

3) Apakah akan semakin menambah beban aparat penegak hukum yang tidak seimbang atau nyata-nyata tidak dapat diemban oleh kemampuan yang dimilikinya.

4) Apakah perbuatan-perbuatan itu menghambat atau menghalangi citacita bangsa, sehingga merupakan bahaya bagi keseluruhan masyarakat.

Undang-Undang Perlindungan Konsumen menetapkan perbuatanperbuatan itu dalam Pasal 61 "Penuntutan pidana dapat dilakukan terhadap pelaku usaha dan/atau pengurusnya". Sanksi pidana sebagaimana dimaksud dalam Pasal 62, dapat dijatuhkan hukuman tambahan, berupa:

1) Pelaku usaha yang melanggar ketentuan sebagaimana dimaksud dalam Pasal 8, Pasal 9, Pasal 10, Pasal 13 ayat (2), Pasal 15, Pasal 17 ayat (1) huruf a, huruf b, huruf c, huruf e, ayat (2), dan Pasal 18 dipidana dengan pidana penjara paling lama 5 (lima) tahun atau pidana denda paling banyak Rp 2.000.000.000,00 (dua miliar rupiah).

2) Pelaku usaha yang melanggar ketentuan sebagaimana dimaksud dalam Pasal 11, Pasal 12, Pasal 13 ayat (1), Pasal 14, Pasal 16, dan Pasal 17 ayat (1) huruf $d$ dan huruf $f$ dipidana dengan pidana penjara paling lama 2 (dua) tahun atau pidana denda paling banyak $\mathrm{Rp}$ 500.000.000,00 (lima ratus juta rupiah). 
3) Terhadap pelanggaran yang mengakibatkan luka berat, sakit berat, cacat tetap atau kematian diberlakukan ketentuan pidana yang berlaku.

Sedangkan terhadap Pasal 63 bisa dikatakan sanksi yang berupa asas di dalam Undang-Undang

1) Perampasan barang tertentu;

2) Pengumuman keputusan hakim;

3) Pembayaran ganti rugi;

4) Perintah penghentian kegiatan tertentu yang menyebabkan timbulnya kerugian konsumen;

5) Kewajiban penarikan barang dari peredaran; atau

6) Pencabutan izin usaha.

Ketentuan pidana yang diatur dalam Undang-Undang Perlindungan Konsumen sebagai upaya perlindungan terhadap masyarakat selaku konsumen. Namun demikian, Pasal 63 UndangUndang Nomor 8 Tahun 1999 tentang Perlindungan Konsumen sebagai upaya perlindungan terhadap konsumen menetapkan bentuk penjatuhan sanksi ganti rugi tanpa menentukan jumlahnya sebagai pidana tambahan. Hal ini ada baiknya untuk memberikan kebebasan bagi hakim dalam penjatuhan putusan tetapi dalam penerapannya seyogyanya tetap memperhatikan kesebandingan antara ganti rugi yang dijatuhkan sebagai pidana tambahan dengan besamya ancaman pidana denda.

\section{SIMPULAN}

Praktik bisnis seminar yang mengandung unsur penipuan yang urgensinya adalah setiap seminar yang diadakan harus dilaporkan kepada Yayasan Lembaga Perlindungan Konsumen terlebih dahulu. Kemudian YLPK mempelajari isi materi yang akan diajarkan atau disampaikan kepada masyarakat terlebih dahulu. Apabila materi yang diajarkan ke Masyarakat tidak ada unsur penipuan, maka YLPK bisa memberi ijin kepada penyelenggara seminar. Akan tetapi, YLPK juga tetap mengawasi jalannya seminar/workshop yang diadakan oleh pelaku usaha tersebut sehingga LPIS tahu kalau penyelenggara seminar tidak curang dengan merahasiakan sebagian ilmu yang diajarkan atau bahkan adanya suatu unsur penipuan pada saat jalannya penyelenggaraan seminar tersebut. Apalagi di dalam kajian Undang-Undang Nomor 8 Tahun 1999 tentang Perlindungan Konsumen belum ada aturan berkaitan dengan tehnis dan mekanisme pencegahan tindakan dalam perilaku praktik bisnis yang menyimpang. Oleh karenanya hal ini merupakan suatu konsep yang sangat bagus dimana hal ini sebagai suatu upaya untuk mengatisipasi adanya "korban" praktik bisnis yang kurang beretika (seperti tidak transparan, dan sebagainya) sehingga merugikan banyak pihak. Pihak disini adalah masyarakat jelas sebagai konsumen terlanggar 
hak-hak normatifnya sebagaimana yang diatur oleh Undang-Undang Nomor 8 Tahun 1999 tentang Perlindungan Konsumen, yang menyatakan bahwa konsumen mempunyai hak terkait dengan informasi yang jelas, benar dan jujur terkait dalam hal kondisi atau keadaan dan jaminan barang ataupun jasa.

\section{DAFTAR PUSTAKA}

Abdul Rasyid Saliman, et.Al. Hukum Bisnis Untuk Perusahaan (Teori dan Contoh Kasus) Edisi 2 Cetakan 4, Jakarta: Kencana Renada Media Group, 2008.

Adami Chazawi. Pelajaran Hukum Pidana Bagian I (Stelsel Pidana, Tindak Pidana, Teori-Teori Pemidanaan \& Batas Berlakunya Hukum Pidana), jakarta: Rajawali Pers, 2010.

Amirullah, dan Imam Hardjanto, Pengantar Bisnis, Edisi Pertama, Yogyakarta: Graha Ilmu, 2005.

Badan Pusat Statistik. Statistik Angka Kemiskinan dan Pengangguran, https://www.bps.go.id/pressrelease/2019/05/06/1564/februari2019--tingkat-pengangguran-terbuka--tpt--sebesar-5-01persen.html pada bulan September 2019

Celina Tri Siwi Kristiyanti. Hukum Perlindungan Konsum Satjipto Rahardjo, Sisi-sisi Lain dari Hukum di Indonesia, Jakarta: Kompas, 2003 en, Grafika, Jakarta: Sinar 2008.

Happy Susanto. Hak-Hak Konsumen Jika dirugikan, Jakarta: Visimedia, 2008. Idris Rusadi Putra, Hati-Hati Penipuan Investasi Berkedok Seminar, Begini Modusnya, Diakses melalui : https://www.merdeka.com/uang/hatihati-penipuan-investasi-berkedok-seminar-begini-modusnya.html, pada bulan September 2019

Indriyo Gitosudarmo. Manajemen Pemasaran. Yogyakarta: BPFE, 2000

Lim Kristanto Sitompul. Pengertian Seminar, Diskusi, Simposium, , dan lukium, https://www.scribd.com/doc/240795123/PengertianSeminar, pada bulan Januari, 2017.

Masruchin Ruba'i, Hukum Pidana I, Malang: IKIP Malang. 1989.

Penjelasan Undang-Undang Nomor 8 Tahun 1999 tentang Perlindungan Konsumen.

Philipus M. Hadjon,dkk, Pengantar Hukum Administrasi Indonesia, Yogyakarta: Gajah Mada University Press, 2011.

Susanti Adi Nugroho. Proses Penyelesaian Sengketa Konsumen Ditinjau Dari Hukum Acara Serta Kendala Implementasinya, Jakarta: Pradana Media Group, 2011. 
Moh Abdul Latif

Halaman ini sengaja dikosongkan 